Éamon P. McCoy MD FFARCSI,

Fiona M. Connolly MB FFARCSI,

Rajinder K. Mirakhur MD PhD FRCA FFARCSI,

Paul B. Loan mrCP frCA, L. Douglas Paxton Mb fFarcsi

\section{Nondepolarizing neuromuscular blocking drugs and train-of-four fade}

sement soit plus grand avec l'atracurium et le racuronium pendant l'établissement du bloc, les différences entre myorelaxants ne sont pas significatives. On conclut que les effets préjonctionnels relatifs de ces myorelaxants sont identiques. cular block. The relaxants studied were atracurium (225 $\mu \mathrm{g} \cdot \mathrm{kg}^{-1}$ ), mivacurium (65 $\mu \mathrm{g} \cdot \mathrm{kg}^{-1}$ ) rocuronium (300 $\mu \mathrm{g} \cdot \mathrm{kg}^{-1}$ ) and vecuronium ( $\left.40 \mu \mathrm{g} \cdot \mathrm{kg}^{-1}\right)$. The TOF ratios were measured at approximate heights of $T_{1}$ (first response in the TOF) of 90, 75, 50, and 25\%. The TOF fade (as shown by lower TOF ratios) increased with a decrease in the $T_{I}$ during onset of neuromuscular block. Although there was a slightly greater fade with atracurium and rocuronium during the onset of block, the differences among the relaxants were insignificant. It is concluded that the relative prejunctional effects of these relaxants are similar.

Ce travail cherche à évaluer la différences entre les effets préjonctionnels de plusieurs myorelaxants par la mesure de l'affaiblissement (fade) de la réponse au train-de-quatre (TOF) pendant l'établissement et la récupération du bloc neuromusculaire. Les relaxants étudiés sont l'atracurium (225 $\left.\mu \mathrm{g} \cdot \mathrm{kg}^{-1}\right)$, le mivacurium (65 $\left.\mu \mathrm{g} \cdot \mathrm{kg}^{-1}\right)$, le rocuronium $\left(300 \mu \mathrm{g} \cdot \mathrm{kg}^{-1}\right)$ et le vécuronium $\left(40 \mu \mathrm{g} \cdot \mathrm{kg}^{-1}\right)$. Les rapports du TOF sont mesurés avec la hauteur approximative du $T_{1}$ (première réponse au TOF) de 90,75, 50 et 25\%. L'affaiblissement du TOF (montré par la baisse du ratio) augmente avec la baisse de $T_{1}$ pendant leétablissement du bloc neuromusculaire. Bien que l'affaiblis-

\section{Key words}

MONITORING: train-of-four;

NEUROMUSCULAR TRANSMISSION: prejunctional effects;

NEUROMUSCULAR RELAXANTS: atracurium, mivacurium, rocuronium, vecuronium.

From the Department of Anaesthetics, The Queen's University of Belfast, and the Royal Hospitals Trust.

Dr. McCoy was supported by a Research Fellowship from the Gifts and Endowments Fund of the Royal Hospitals Trust.

Address correspondence to: Dr. R.K. Mirakhur, Department of Anaesthetics, The Queen's University of Belfast, The Whitla Medical Building, 97 Lisburn Road, Belfast BT9 7BL, Northern Ireland.

Accepted for publication 21st November, 1994.
Although the site of action of nondepolarizing relaxants is predominantly postjunctional, they may also have a prejunctional site of action. ${ }^{1-4}$ Different neuromuscular blocking drugs, however, have been shown to have different degrees of prejunctional effects as shown by different degrees of fade in response to a train-of-four (TOF) stimulation. ${ }^{2,5-7}$. The relative prejunctional effects of the newer muscle relaxants, mivacurium and rocuronium, as measured by TOF fade, particularly in relation to agents like atracurium and vecuronium, are not well known, nor is it known if this activity is related to the rate of onset of block. This has been investigated in the present study.

\section{Methods}

Forty adult patients, of ASA grades I or II, were included in the study after obtaining their written informed consent and approval of the Regional Ethics Committee. All were scheduled to undergo elective operative procedures requiring the use of nondepolarizing neuromuscular blocking agents. Following premedication with oral temazepam $10-20 \mathrm{mg}, 60-90 \mathrm{~min}$ preoperatively, anaesthesia was induced with fentanyl 2-3 $\mu \mathrm{g} \cdot \mathrm{kg}^{-1}$ and thiopentone 5-6 $\mathrm{mg} \cdot \mathrm{kg}^{-1}$, and maintained with $66 \%$ nitrous oxide in oxygen and further increments of fentanyl and/or thiopentone as required. Heart rate, arterial blood pressure, oxygen saturation, end-tidal $\mathrm{CO}_{2}$ and temperature were monitored in every patient. Ventilation was adjusted to maintain the end-tidal carbon dioxide between 4.5 and $5.0 \%$ and the arm was wrapped in cotton wool to keep the skin temperature above $32^{\circ} \mathrm{C}$. No volatile agents were used during the study period. Neuromuscular monitoring consisted of stimulation of the ulnar nerve at the wrist with supramaximal stimuli of $0.2 \mathrm{msec}$ duration in a train-of-four (TOF) mode at $2 \mathrm{~Hz}$ every $12 \mathrm{sec}$ and recording the force of contraction of the adductor pollicis 
muscle using a force transducer and a neuromuscular function analyzer (Myograph 2000, Biometer Ltd, Denmark).

Following a ten-minute period of stabilization of control TOF responses, ten patients each were randomly allocated to receive atracurium $225 \mu \mathrm{g} \cdot \mathrm{kg}^{-1}$, vecuronium $40 \mu \mathrm{g} \cdot \mathrm{kg}^{-1}$, mivacurium $65 \mu \mathrm{g} \cdot \mathrm{kg}^{-1}$ or rocuronium 300 $\mu \mathrm{g} \cdot \mathrm{kg}^{-1}$, these being the approximate $\mathrm{ED}_{95}$ doses of these relaxants. The TOF ratios, i.e., the ratio of the heights of the fourth $\left(T_{4}\right)$ to the first $\left(T_{1}\right)$ twitch in the same train, were calculated at approximate heights of $\mathrm{T}_{1}$ of $90,75,50$ and $25 \%$ of control during both the onset of the block and spontaneous recovery. The time to attain $90 \%$ block of the $T_{1}$ and the degree of maximum block attained was also recorded.

The statistical significance of the results was tested using analysis of variance followed by $t$ tests with Bonferroni correction if required. A $P$ value of $<0.05$ was taken to represent a significant difference.

\section{Results}

The patients in the four groups were comparable with regard to age, weight and height (Table I).

The TOF ratios with the four relaxants at $90,75,50$ and $25 \%$ of $T_{1}$ during the onset of block are given in Table II. The end-points could not be recorded at all times, particularly with rocuronium as the $T_{1}$ sometimes decreased in height rapidly. It is clear that fade increases as the height of the $\mathrm{T}_{1}$ decreases from 90 to $25 \%$ of control with all four relaxants as shown by decreasing TOF ratios with increasing block. Although TOF ratios with rocuronium and atracurium were slightly lower, particularly at $T_{1}$ of 50 and $25 \%$, the differences were not statistically significant. The time to $90 \%$ depression of $T_{1}$ was shorter with rocuronium than with the other three relaxants, being $52 \mathrm{sec}$ compared with 128,147 and 136 sec with atracurium, mivacurium and vecuronium respectively $(P<0.01)$. All but one patient receiving atracurium and two receiving mivacurium developed $90 \%$ or greater block (Table II). The $T_{1}$ depression in these patients was 68 , and 40 and $54 \%$ respectively. The mean values, however, were not significantly different.

The TOF ratios during recovery of neuromuscular block (Table III) were lower in comparison with the ratios during onset of block at each of the measured heights of $T_{1}$. However, there was no significant difference between the relaxants at any of the assessment points.

\section{Discussion}

During repetitive nerve stimulation, nondepolarizing relaxants, in addition to depressing the amplitude of contractions, also cause varying degrees of fade in response to TOF or tetanic stimulation. ${ }^{3}$ Fade produced by non-
TABLE I Demographic data (mean \pm SD)

\begin{tabular}{lllll}
\hline & $n$ & Age $(y r)$ & Weight $(\mathrm{kg})$ & Height $(\mathrm{cm})$ \\
\hline Atracurium & 10 & $35 \pm 13.5$ & $63 \pm 11.7$ & $162 \pm 6.8$ \\
Mivacurium & 10 & $36 \pm 15.9$ & $68 \pm 10.6$ & $167 \pm 9.8$ \\
Rocuronium & 10 & $46 \pm 14.8$ & $65 \pm 11.1$ & $163 \pm 11.6$ \\
Vecuronium & 10 & $39 \pm 10.4$ & $66 \pm 9.6$ & $166 \pm 9.1$ \\
\hline
\end{tabular}

depolarizing neuromuscular blocking drugs in intact muscles in response to higher rates of stimulation (such as TOF and tetany) has been suggested to be due to prejunctional actions of the drugs causing inhibition by a nicotinic receptor-mediated positive feedback of transmitter release. ${ }^{3,8}$ Therefore the greater the fade, the greater is thought to be the prejunctional effect. The mechanism of the prejunctional effect is perhaps, decreased transmitter output. ${ }^{2,8,9}$

The present study has shown no differences among the four relaxants examined in the relative degree of fade. A previous study showed greater fade with atracurium than with vecuronium. ${ }^{7}$ Although the TOF ratios in the present study were also lower with atracurium than with vecuronium, the differences were smaller and not statistically significant, when an overall comparison of all four drugs was made. Of the newer relaxants, rocuronium showed slightly greater fade, but in general there were no differences which suggests relatively similar prejunctional effects with them. It is possible that this may be due to rapid onset of block with rocuronium allowing little time for development of fade. However, absence of any greater prejunctional effect with rocuronium has also been shown in a more controlled in-vitro study. ${ }^{10}$ Greater fade during recovery of block than during onset of block is well known. This phenomenon was observed in the present study and has been reported with other relaxants also."

The relevance of prejunctional effects of muscle relaxants is unclear at this stage, apart from explaining the site of their action. The clinical importance of the effect is also not clear but it does not appear to be an important factor in the speed of onset of neuromuscular block. A greater prejunctional effect does not appear to be associated with a more rapid onset since $d$ tubocurarine, with a greater prejunctional effect, is not more rapid-acting than pancuronium, nor is atracurium any faster-acting than vecuronium even though it has a greater prejunctional effect. $2,6,7,11-13$ Since the extent of the prejunctional effects of rocuronium is similar to the other relaxants used in the present study, it is unlikely that prejunctional activity has any relation to the rapid onset of its effect as observed in this study and as reported by others. ${ }^{14-17}$ The rapid onset is perhaps related to its 
TABLE II TOF ratios during onset of neuromuscular block with atracurium, mivacurium, rocuronium and vecuronium at different heights of $T_{1}$; also shown is the time taken for $90 \%$ block of $T_{1}$ and the degree of maximum block in each group (mean $\pm S D$ )

\begin{tabular}{llllllll}
\hline & & & & & Time to 90\% & $\begin{array}{l}\text { Degree of maximum } \\
\text { block (\%) }\end{array}$ \\
\hline Atracurium & 10 & $83 \pm 8.0$ & $74 \pm 8.7$ & $57 \pm 16.4$ & $47 \pm 12.3^{\mathrm{a}}$ & $128 \pm 63.1$ & $96 \pm 10.0$ \\
Mivacurium & 10 & $86 \pm 9.9$ & $76 \pm 7.5$ & $69 \pm 7.2^{\mathrm{a}}$ & $52 \pm 9.1^{\mathrm{b}}$ & $147 \pm 50.5$ & $87 \pm 21.6$ \\
Rocuronium & 10 & $87 \pm 6.2^{\mathrm{c}}$ & $70 \pm 9.5^{\mathrm{d}}$ & $59 \pm 12.9^{\mathrm{e}}$ & $47 \pm 11.7^{\mathrm{r}}$ & $52 \pm 11.0$ & $99 \pm 1.4$ \\
Vecuronium & 10 & $89 \pm 3.9^{\mathrm{a}}$ & $82 \pm 3.2$ & $70 \pm 3.4$ & $52 \pm 7.2$ & $136 \pm 47.0$ & $98 \pm 2.8$ \\
\hline
\end{tabular}

${ }^{a} n=9 ;{ }^{b} n=8 ; c_{n}=6 ;{ }^{d} n=4 ;{ }^{e} n=5 ; i_{n}=7$; in other cases the height of $T_{1}$ during the onset of block did not correspond to any of the end-points at which the TOF was recorded.

TABLE III TOF ratios (mean $\pm \mathrm{SD}$ ) during recovery from neuromuscular block with atracurium, mivacurium, rocuronium and vecuronium

\begin{tabular}{lcccll}
\hline & $n$ & $T_{1} 25 \%$ & $T_{1} 50 \%$ & $T_{1} 75 \%$ & $T_{1} 90 \%$ \\
\hline Atracurium & 10 & $15 \pm 9.3^{\mathrm{a}}$ & $27 \pm 14.7$ & $42 \pm 14.6^{\mathrm{b} *}$ & $61 \pm 13.1^{\mathrm{b} *}$ \\
Mivacurium & 10 & $13 \pm 4.0^{\mathrm{c}}$ & $23 \pm 5.6^{\mathrm{d}}$ & $43 \pm 12.4$ & $61 \pm 12.1$ \\
Rocuronium & 10 & $18 \pm 9.1^{\mathrm{e}}$ & $22 \pm 13.8$ & $41 \pm 13.5$ & $53 \pm 14.4$ \\
Vecuronium & 10 & $12 \pm 4.3^{\mathrm{f}}$ & $25 \pm 14.5$ & $47 \pm 17.7$ & $60 \pm 16.6$ \\
\hline
\end{tabular}

${ }^{\mathrm{a}} n=7 ;{ }^{\mathrm{b}} n=9 ;{ }^{\mathrm{c}} n=5 ;{ }^{\mathrm{d}} n=8 ;{ }^{\mathrm{e}} n=3 ; \mathrm{i}_{n}=4$; in others the fourth response in the TOF was not present at this stage; *data not recorded for one patient at these points due to mechanical problems.

lower potency. ${ }^{18,19}$ The prejunctional effects may be important when a drug with relatively greater prejunctional effects is administered along with a drug with predominantly postjunctional effects, when there may both be a potentiation of effect as well as a more rapid onset with the combination. ${ }^{20-23} \mathrm{~A}$ possible role for the prejunctional effects has also been suggested in an experimental study in the prevention of succinylcholine-induced fasciculations by d-tubocurarine. ${ }^{24}$ However, others have observed no difference between d-tubocurarine and vecuronium, two drugs with different relative prejunctional effects, in reducing succinylcholine-induced myalgias and fasciculations. ${ }^{25}$

The extent of prejunctional effects may be related to potency as low potency drugs tend to show greater TOF fade. ${ }^{7}$ This is not supported by the findings of the present study and any such relationship needs examination.

A previous study has shown that the degree of fade at any particular height of $T_{1}$ is greater with higher doses. ${ }^{7}$ In the present study only lower doses of relaxants were used in order to be able to measure the fade (TOF ratios) at various points during the onset of block; higher doses of rocuronium produce a very rapid onset of effect making it difficult to obtain the fade at different heights of $T_{1}$.

In conclusion, the present study showed no differences in the TOF fade with atracurium, vecuronium, mivac- urium and rocuronium. Any pharmacodynamic differences are therefore related to factors other than their relative prejunctional effects.

\section{References}

1 Blaber LC. The prejunctional actions of some nondepolarizing blocking drugs. Br J Pharmacol 1973; 47: 109-16.

2 Bowman WC, Webb SN. Tetanic fade during partial transmission failure produced by non-depolarising neuromuscular blocking drugs in the cat. Clin Exp Pharmacol Physiol 1976; 3: 545-55.

3 Bowman WC. Prejunctional and postjunctional cholinoceptors at the neuromuscular junction. Anesth Analg 1980; 59: 935-43.

4 Galindo $A$. The role of prejunctional effects in myoneural transmission. Anesthesiology 1972; 36: 598-608.

5 Williams NE, Webb FN, Calvey TN. Differential effects of myoneural blocking drugs of neuromuscular transmission. Br J Anaesth 1980; 52: 1111-5.

6 Stanec A, Baker T. Prejunctional and postjunctional effects of tubocurarine and pancuronium in man. $\mathrm{Br} \mathrm{J}$ Anaesth 1984; 56: 607-11.

7 Gibson FM, Mirakhur RK. Train-of-four fade during onset of neuromuscular block with nondepolarising neuromuscular blocking agents. Acta Anaesthesiol Scand 1989; 33: 204-6.

8 Gibb AJ, Marshall IG. Pre- and post-junctional effects of tubocurarine and other nicotinic antagonists during repetitive stimulation in the rat. J Physiol 1984; 351: 275-97.

9 Hubbard JI, Wilson DF. Neuromuscular transmission in a mammalian preparation in the absence of blocking drugs and the effect of D-tubocurarine. J Physiol (Lond) 1973; 228: 307-25.

10 Tian L, Mehta MP, Prior C, Marshall IG. Relative preand postjunctional effects of a new vecuronium analogue, ORG 9426, at the rat neuromuscular junction. $\mathrm{Br} J$ Anaesth 1992; 69: 284-7.

11 Pearce $A C$, Casson WR, Jones RM. Factors affecting train-of-four fade. Br J Anaesth 1985; 57: 602-6.

12 Krieg N, Crul JF, Booij LHDJ. Relative potency of ORG 
NC 45, pancuronium, alcuronium and tubocurarine in anaesthetized man. Br J Anaesth 1980; 52: 783-8.

13 Robertson EN, Booij LHDJ, Fragen RJ, Crul JF. Clinical comparison of atracurium and vecuronium (ORG NC 45). Br J Anaesth 1983; 55: 125-34.

14 Wierda JMKH, De Wit APM, Kuizenga K, Agoston S. Clinical observations on the neuromuscular blocking action of ORG 9426, a new steroidal non-depolarizing agent. $\mathrm{Br} \mathrm{J}$ Anaesth 1990; 64: 521-3.

15 Cooper R, Mirakhur RK, Clarke RSJ, Boules Z. Comparison of intubating conditions after administration of ORG 9426 (rocuronium) and suxamethonium. $\mathrm{Br} \mathbf{J}$ Anaesth 1992; 69: 269-72.

16 Cooper RA, Mirakhur RK, Maddineni VR. Neuromuscular effects of rocuronium bromide (Org 9426) during fentanyl and halothane anaesthesia. Anaesthesia 1993; 48: 103-5.

17 Foldes FF, Nagashima H, Nguyen HD, Schiller WS, Mason MM, Ohta Y. The neuromuscular effects of ORG 9426 in patients receiving balanced anesthesia. Anesthesiology 1991; 75: 191-6.

18 Bowman WC, Rodger IW, Houston J, Marshall RJ, McIndewar I. Structure:action relationships among some desacetoxy analogues of pancuronium and vecuronium in the anesthetized cat. Anesthesiology 1988; 69: 57-62.

19 Bartkowski RR, Witkowski TA, Azad S, Lessin J, Marr A. Rocuronium onset of action: a comparison with atracurium and vecuronium. Anesth Analg 1993; 77: 574-8.

20 Mirakhur RK, Pandit SK, Ferres CJ, Gibson FM. Time course of muscle relaxation with a combination of pancuronium and tubocurarine. Anesth Analg 1984; 63: 437-40.

21 Mirakhur RK, Gibson FM, Ferres CJ. Vecuronium and $d$ tubocurarine combination: potentiation of effect. Anesth Analg 1985; 64: 711-4.

22 Lebowitz PW, Ramsey SM, Savarese JJ, Ali HH. Potentiation of neuromuscular blockade in man produced by combinations of pancuronium and metocurine or pancuronium and $d$-tubocurarine. Anesth Analg 1980; 59: 604-9.

23 Lebowiz PW, Ramsay SM, Savarese JJ, Ali HH, deBros $F M$. Combination of pancuronium and metocurine: neuromuscular and hemodynamic advantages over pancuronium alone. Anesth Analg 1981; 60: 12-7.

24 Hartman GS, Flamengo SA, Riker WF Jr. Succinylcholine: mechanism of fasciculations and their prevention by d-tubocurarine or diphenylhydantoin. Anesthesiology 1986; 65: 405-13.

25 Ferres CJ, Mirakhur RK, Craig HJL, Browne ES, Clarke RSJ. Pretreatment with vecuronium as a prophylactic against post-suxamethonium muscle pain: comparison with other non-depolarising neuromuscular blocking drugs. $\mathrm{Br} \mathbf{J}$ Anaesth 1983; 55: 735-41. 